\title{
Where now for protected areas? Setting the stage for the 2014 World Parks Congress
}

\author{
Nigel Dudley, Craig Groves, Kent H. Redford and Sue Stolton
}

\begin{abstract}
Protected areas are regarded as the most important tool in the conservation toolbox. They cover $>12 \%$ of the Earth's terrestrial area, with over half of this designated since 1970, and are thus a unique example of governments and other stakeholders consciously changing management of land and water at a significant scale. The Convention on Biological Diversity (CBD) has a global programme to complete ecologically-representative protected area networks, and this is driving the creation of large numbers of new protected areas. But there is also growing criticism of protected areas because of the social costs of protection and doubts about their effectiveness. We acknowledge this criticism but believe that it is over-stated and applied to a protected area model that has already been replaced by newer thinking. As protected areas are becoming more complex in concept and more complicated in management, we review the six most important changes affecting them over the last 2 decades: (1) a new protected area definition with more emphasis on nature conservation; (2) a plurality of management and governance models; (3) acknowledgement of wider protected area benefits beyond nature conservation; (4) greater social safeguards for protected areas; (5) evidence that protected areas are effective conservation tools; and (6) a new emphasis on larger protected areas, transboundary protected areas, connectivity conservation and landscape approaches. We conclude by considering fresh challenges as a result of policy changes and the global criminal wildlife trade, and consider the potential of the forthcoming 2014 IUCN World Parks Congress.
\end{abstract}

Keywords Ecosystem services, IUCN, management effectiveness, protected areas, World Parks Congress

\section{Introduction}

Protected areas are the cornerstone of most national conservation strategies. They cover c. $12.7 \%$ of the land

Nigel DudleY* (Corresponding author) and Sue Stolton Equilibrium Research, 47 The Quays, Cumberland Road, Bristol BS1 6UQ, UK

E-mail nigel@equilibriumresearch.com

Craig Groves The Nature Conservancy, Bozeman, Montana, USA

Kent H. RedFord Archipelago Consulting, Portland, Maine, USA

* Also at: School of Geography, Planning and Environmental Management, University of Queensland, Australia

Received 19 March 2014. Revision requested 3 June 2014.

Accepted 24 June 2014. First published online 25 July 2014. surface outside Antarctica, 7.2\% of coastal waters and small areas of the high seas, with marine and freshwater protected area systems in particular undergoing rapid expansion (Bertzky et al., 2012). Over half have been designated since 1970; a unique example of governments and other stakeholders consciously changing management of land and water at a significant scale globally. If all private and community-managed reserves were included in the World Database on Protected Areas (WDPA), the total would be even greater. The Convention on Biological Diversity (CBD) Programme of Work on Protected Areas, agreed in 2004, aims to 'establish and strengthen national and regional systems of protected areas integrated into a global network' (CBD, 2004). At the 1oth Conference of Parties to the CBD in 2010 signatory states agreed to expand the Programme of Work, setting a target of at least $17 \%$ of terrestrial and inland water areas and $10 \%$ of coastal and marine areas to be conserved through protected areas and other effective areabased conservation measures by 2020 (CBD, 2010). Unlike other targets set by the international community, protected area establishment has provided the CBD with some rare conservation successes. A number of conservation biologists argue that the targets remain too low (e.g. Locke, 2013) and that uneven distribution of species makes percentage targets too simplistic (Rodrigues et al., 2004; Svancara et al., 2005). Nonetheless, such a broad intergovernmental recognition of the need to set aside natural ecosystems from development is significant.

Yet protected areas are also attracting growing criticism on both social and ecological grounds. Some social scientists, human rights activists and indigenous peoples' groups and supporters are concerned that establishment of protected areas can result in indigenous peoples and local communities being dispossessed of their traditional lands and resources (e.g. Colchester, 2003; Brockington et al., 2008; Dowie, 2009; Duffy, 2010). Others fear that protected area managers will only work with indigenous peoples as long as the latter do not wish to undergo development (Holt, 2005). Protected areas that exclude people are out of step with the imperatives of environmental justice and efforts to mainstream conservation into the wider landscape (Lele et al., 2010). Rights-based approaches in protected areas are being demanded to an increasing extent (Campese et al., 2009).

Concurrently, the continuing decline of biodiversity (Butchart et al., 2010), including within some protected areas (Craigie et al., 2010; Fitzsimons et al., 2010), has created doubts about the efficacy of protected areas as tools 
to conserve biodiversity, particularly given their insufficient coverage (e.g. Mora \& Sale, 2011), ecological isolation (e.g. Archer \& Beale, 2004), lack of ecological representation (Rodrigues et al., 2004), bias towards the least productive lands (e.g. Scott et al., 2001), and the likelihood of species moving outside reserves as a result of the ecosystem shifts caused by climate change (Lawler et al., 2009).

Here we argue that although many of these criticisms were once valid, they are inconsistent with the revised global approach to protected area establishment and management that has emerged over the past 2 decades or more. The traditional, top-down, exclusionary management model they address was explicitly rejected as global-level policy at the Vth World Parks Congress in 2003 (IUCN, 2005) and abandoned in practice much earlier in some parts of the world. Protected areas have continued to change as a result of these criticisms, although there remains much to be done both at an international policy level and in practice. We review the six most important changes that are currently influencing the conservation effectiveness and social acceptance of protected areas. Analysis of these trends draws on existing data sets, published literature and our own collective experience of decades working in protected areas globally. We conclude by examining these changes in light of the criticisms outlined above and discuss what broader implications they have for protected areas in the future.

\section{(1) A new protected area definition with more emphasis on nature conservation}

Defining protected areas helps us understand the world's global protected area estate using a common language. The previous IUCN definition of a protected area (IUCN/ WCMC, 1994) was 'An area of land and/or sea especially dedicated to the protection and maintenance of biological diversity, and of natural and associated cultural resources, and managed through legal or other effective means.' Following extensive consultation amongst IUCN members, it was replaced in 2008 by 'A clearly defined geographical space, recognized, dedicated and managed, through legal or other effective means, to achieve the long-term conservation of nature with associated ecosystem services and cultural values' (Dudley, 2008). This was accompanied by a principle: 'For IUCN, only those areas where the main objective is conserving nature can be considered protected areas; this can include many areas with other goals as well, at the same level, but in the case of conflict, nature conservation will be the priority' (ibid.). This new definition clarifies that protected areas should be managed primarily for conservation (although it says nothing about selecting new protected areas on the basis of high conservation values). It changes the focus from 'biological diversity' to 'nature conservation', recognizing the importance of geology and landform, that 'biological diversity' is not a widely recognized term with the general public, and that 'nature' has broader cultural and spiritual dimensions for many stakeholders (Dudley et al., 2010). The definition and principles apply to both new and existing protected areas and are gradually affecting policy in individual countries. In the UK, for example, all major protected area designations now have a Statement of Compliance explaining how the area matches the IUCN definition (IUCN NCUK, 2012).

\section{(2) A plurality of management and governance models}

Management and governance of protected areas is becoming increasingly varied and flexible to national and local needs. Since 1994 IUCN has recognized six management approaches, ranging from sites where human access is banned or strictly controlled to cultural landscapes or seascapes that contain settled human communities and encourage sustainable resource use (Dudley, 2008). Although there have been criticisms of less restrictive categories (e.g. Locke \& Deardon, 2005), stimulating some significant responses (e.g. Mallarach et al., 2008; Ferraro et al., 2013), all categories are now widely accepted as playing an important role within the conservation landscape and are increasingly applied within protected area systems (Bertzky et al., 2012). Managers of existing protected areas are also experimenting with new approaches. Some previously restricted areas are, for example, opening borders to limited use such as sustainable collection of non-timber forest products (e.g. Bwindi Impenetrable Forest in Uganda) and access to sacred sites (e.g. Nyika Plateau, Malawi), thus making greater efforts to increase benefits without prejudicing conservation needs. While less restrictive management policies are popular in places with significant human populations, this is not invariably the case: for example, strict protection is sometimes being requested by communities to protect sacred natural sites (Bhagwat \& Rutte, 2006).

Another step towards greater pluralism is embodied in the wider variety of governance models used to establish and manage protected areas, including sub-national government agencies, private entities (especially NGOs), indigenous peoples, local communities, and various kinds of shared governance. Privately protected areas, managed by private individuals or by for-profit and non-profit enterprises, are increasingly an important conservation tool (Pasquini et al., 2011) but have until recently been virtually ignored by many governments and omitted from the WDPA; this situation is now changing through a global effort to review the status and trends of such areas and to suggest needed reforms (Stolton et al., in press). The growth of privately protected areas demonstrates an increasingly bottom-up approach to conservation, with individuals and groups 
of concerned citizens taking the initiative. Indigenous and community conserved areas, managed formally or informally, often by disenfranchised members of society (Berkes, 2009), have traditionally had an even lower profile with governments. Inclusion of such areas within the CBD Programme of Work on Protected Areas (CBD, 2004) and recognition by IUCN (Dudley, 2008) have provided official endorsement. Indigenous and community conserved areas indicate growing acceptance by some indigenous peoples and local communities that integration of traditionally-managed territories into governmentsponsored protected area systems can offer benefits in terms of funding, legal protection and political influence (Redford \& Painter, 2006). The conservation effectiveness of both privately protected areas (Rissman \& Sayre, 2012) and indigenous and community conserved areas (Nelson \& Chomitz, 2011) is also being recognized. However, they are not all listed on the WDPA, and a major effort is needed to address this.

\section{(3) Acknowledgement of wider protected area benefits beyond nature conservation}

In parallel with an increased policy emphasis on nature conservation in protected areas, there is also acknowledgement that protected areas supply many other important goods and services (Stolton \& Dudley, 2010a,b; Dudley et al., 2011a,b). Over a third of the world's 100 largest cities rely on forest and wetland protected areas for a significant proportion of their drinking water (Dudley \& Stolton, 2003). Protected areas increase food security by conserving crop wild relatives for crop breeding (Stolton et al., 2008a) and helping maintain freshwater and marine fish stocks (Halpern, 2003). They have direct and indirect health benefits, including conservation of medically-important species for both local use and pharmaceutical production, as places for exercise and in the treatment of mental patients (Stolton \& Dudley, 2010a,b). Protected areas can in some instances prevent extreme climatic events and earthquakes from developing into disasters (Stolton et al., 2008b); e.g. by maintaining forests on slopes to prevent landslides (Perret et al., 2004), absorbing tidal surges and storms in coral reefs and mangroves (Das \& Vincent, 2009), and preventing desertification and dust storms (Al-Dousari, 2009). They are also the world's largest managed carbon stores (Dudley et al., 2009b), containing at least $15 \%$ of the world's terrestrial carbon (Campbell et al., 2008). For instance, protected areas of Bolivia, Venezuela and Mexico store $>4$ billion $\mathrm{t}$ of carbon (Emerton \& Pabon-Zamora, 2009). Protected areas also fulfil cultural and spiritual needs, provide iconic tourist destinations (with associated revenue streams) and protect numerous sacred natural sites (Dudley et al., 2009a), which themselves often have important biodiversity values (Dudley et al., 2010).
Some, but not all, of these values can be translated into economic returns for protected areas and/or resident or local communities through, for example, jobs and payment for ecosystem service schemes. Viewed collectively, research in individual protected areas in places such as Botswana (Mbaiwa, 2004), Canada (Hvenegaard et al., 1989), China (He et al., 2008), India (Ninan \& Sathyapalan, 2005), Indonesia (Van Beukering et al., 2003), New Zealand (Department of Conservation, 2007) and Paraguay (Naidoo \& Ricketts, 2006) has increased recognition of the potential for generating economic value from protected areas. In some countries, such as Rwanda (Maekawa et al., 2013), tourism associated with protected areas is the major source of foreign exchange. There have also been studies of the role that protected areas play in poverty reduction, particularly by improving people's lives in economically depressed rural areas (Andam et al., 2010; Dudley et al., 2011a,b; Ferraro \& Hanauer, 2014). However, this emphasis on benefits and economic values has sometimes led to unrealistic expectations that all protected areas should be able to pay their own way without further support.

\section{(4) Greater social safeguards for protected areas}

In response to evidence that some protected areas have undermined some local peoples' livelihoods, the international community has increased social safeguards around protected areas. The CBD Programme of Work on Protected Areas contains requirements for equitable sharing of costs and benefits, full and effective participation of indigenous and local communities and free and prior informed consent in the establishment of protected areas, for example: '2.2.5 Ensure that any resettlement of indigenous communities as a consequence of the establishment or management of protected areas will only take place with their prior informed consent that may be given according to national legislation and applicable international obligations (CBD, 2004)'. Seen in this light, protected areas are now subject to more rigorous human rights controls than most other forms of state land use (such as resource extraction, transport links, hospitals, airports), which generally reserve the right for compulsory purchase and resettlement. Similarly, donors such as the UN's Global Environmental Facility are introducing more stringent safeguards for local communities in grants and loans relating to conservation, covering conflict resolution, compensation and participation (Global Environmental Facility, 2013).

It would be naive to assume that all countries always apply free and prior informed consent and other social safeguards in practice, or that donor safeguard mechanisms work perfectly. But the text in the Programme of Work on Protected Areas is both a reflection of and stimulant for new and emerging socially-driven approaches to conservation that have seen fundamental changes in the ways that 
governments and protected area agencies do business with communities. Over 20 million hectares of protected areas have been self-declared in Australian aboriginal territories over the past few years, for example (Smyth, 2006). Elsewhere, governments and communities are cooperating to mutual advantage: for example the Orito Ingi Ande Sanctuary in Colombia was established jointly between the state protected area agency and the Kofán people to conserve biodiversity, including important medicinal plants, along with the traditional knowledge about how these are used (Parques Nacionales Naturales de Colombia, 2007).

\section{(5) Evidence that protected areas are effective conservation tools}

Data are becoming available to help us answer questions about the effectiveness of protected areas as conservation strategies. Over the last decade our understanding of how to manage protected areas effectively has grown rapidly (Hockings et al., 2004), with the development and application of a range of assessment tools, a series of individual studies and analysis of $>8,000$ protected area assessments to identify trends in effectiveness and factors in success and failure (Leverington et al., 2010) and the subsequent development of management standards (Conservation Assured, 2013). In parallel, scientists have started collating long-term biological records from in and around protected areas, including under the auspices of an IUCN World Commission on Protected Areas and Species Survival Commission Task Force on Biodiversity and Protected Areas. The evidence suggests that in most situations protected areas are more effective at protecting natural vegetation than alternative land management approaches (e.g. Joppa et al., 2008; Nagendra, 2008; Nelson \& Chomitz, 2011), although exceptions occur (e.g. Clark et al., 2013) and in some other cases the reduction in deforestation from protected areas is only quite modest (Miteva et al., 2012). Protected areas also appear to be generally successful at conserving many plant and animal groups; for example, an analysis of birds, other vertebrates and conifers in Important Bird Areas and Alliance for Zero Extinction Sites found that extinction risk decreased with protected areas coverage (Butchart et al., 2012). Similarly a major literature review concluded that protected areas deliver positive outcomes, albeit that the evidence remains weak and there is a poor understanding of the conditions under which protected areas succeed or fail to deliver positive conservation outcomes (Geldmann et al., 2013). In summary, protected areas do not conserve all species in all circumstances but overall evidence for their effectiveness has increased markedly in the past 5 years. At the same time, we acknowledge that rigorous analyses of protected areas that can statistically infer causal evidence of benefits remain rare (Miteva et al., 2012) and that such evaluations should be a high priority in the future for protected area advocates, managers, planners, and scientists. The recent work of Andam et al. (2010) and Ferraro et al. (2013), who have demonstrated rigorously that protected areas in Thailand and Costa Rica have contributed to poverty reduction, is exemplary in this regard.

\section{(6) New emphasis on larger protected areas, transboundary protected areas, connectivity and landscape approaches}

Protected areas of all sizes have an important role to play in conservation. However, recognition that many protected areas are too small to support viable populations of some species in the long term, and too isolated from other suitable ecosystems to allow genetic interchange (e.g. Newmark, 1995) has focused attention on the significance of larger protected areas, transboundary protected areas (Vasilijević et al., in press), connectivity conservation and the integration of protected areas into wider landscape approaches (e.g. Beier et al., 2008; Beever et al., 2014). New large-scale initiatives have emerged in the last decade, such as the Great Eastern Ranges Initiative in Australia, the Florida Wildlife Corridor in the United States, the Terai Arc Landscape Project in Nepal and the Amazon Region Protected Area programme. All draw on principles of conservation planning to develop ecologically functional mosaics of protected areas, often in combination with other management approaches deemed supportive of biodiversity.

Concurrently, governments of neighbouring states have launched joint initiatives to develop coherent and connected protected area networks, such as the Micronesia Challenge and Caribbean Challenge. A growing number of governments are also prepared to cooperate across national borders in protected area management. Between the late 1980 s and 2007 , transboundary protected areas increased from 59 to 227 complexes involving 3,043 individual protected areas (Lysenko et al., 2007). Collaborations can be informal agreements to collaborate, built around individual trust between managers or rangers across national boundaries, or more formal government-led processes, ranging from signed memoranda of understanding to cross-border treaties.

\section{Discussion}

We began by listing some common criticisms of protected areas. We believe that these negative assessments assume attitudes to protection that are now held by few contemporary conservation biologists or protected area specialists. Such assessments fail to recognize that major changes have occurred over the last 2 decades in protected area philosophy, in the expectations placed on protected areas and in the pressures facing the natural world. This is not to deny the existence of some socially repressive or ecologically 
ineffective protected areas or to downplay the urgency of addressing these failings. But the associated problems are neither inherent nor inevitable. Far from being a static institution, the protected area estate has always been undergoing change and the rate of change is accelerating with respect to management approaches and governance, in regard to the social and political expectations that protected areas face, and in understanding what is needed for them to function as effective conservation tools.

These changes will continue. Protected areas are coming under increasing pressure in some countries. On a regional scale, land degradation increased by $250 \%$ during 2004-2009 in protected areas of Latin America, with habitat loss of $>_{1}$ million ha (Leisher et al., 2013). Globally, recent analyses have highlighted extensive but episodic efforts of protected area downgrading, downsizing, and degazettement (Mascia et al., 2014). The illegal wildlife trade has escalated, with knock-on effects on species in protected areas. It is now valued at USD 5-20 billion per year (Rosen \& Smith, 2010), driven by high demand for traditional medicines in the newly wealthy countries of China and Vietnam and the taste for bushmeat amongst the middle class throughout the developing world. Traders rapidly shift country and technique, with a rapidity that takes protected area agencies by surprise, as evidenced by the 668 rhinoceros poached in Africa in 2011 after years with poaching at a low level (Collins et al., 2013). In crisis conditions, strategists are focusing on protected areas to provide defendable, core conservation areas (Walston et al., 2010).

Protected area managers are also starting to respond to the challenges created by climate change. Projections suggest that many protected areas will continue to contain significant numbers of species (Hannah et al., 2007), with species expanding their ranges into existing protected areas (Johnston et al., 2013), and intact, functioning ecosystems withstanding a changing climate better than degraded, fragmented ecosystems (Mawdsley et al., 2009). However, more species are likely to become reliant on active management for their survival (Scott et al., 2010). Difficult decisions will need to be made on issues such as assisted migration and management of novel ecosystems, and establishing appropriate goals and objectives for protected areas in relation to climate change impacts, adaptation, and mitigation will be challenging for managers (Heller \& Hobbs, 2014). Increased attention to climate change resilience, adaptation and mitigation in protected areas may soon create a seventh important trend in addition to the six changes outlined above.

As we have outlined, the new model of protected area design is more flexible than formerly in terms of management approaches and the question of who makes decisions about planning and management, albeit within the framework of a tighter, more focused definition of the aims of protected areas. It is grounded within a rigorous approach to nature conservation, whilst also acknowledging and managing for a plethora of other social, cultural and economic values that rely on functioning ecosystems. The additional social safeguards make the process of planning and management slower and more complex but result in greater long-term support. Conservation benefits are not assumed but are carefully monitored, and management is adapted as required. The new model looks beyond the protected area boundary, at how to connect functionally with other protected areas and other natural ecosystems, and how to connect socially and economically into wider society. Finally, new financing mechanisms and new partnerships with stakeholders not traditionally concerned with conservation issues are both essential components of a revitalized global protected areas network.

Of course, ideals are never achieved completely. Much remains to be learnt about the science and policy of protected areas. The sixth World Parks Congress, which will take place in Sydney, Australia in November 2014, provides an opportunity to refine further the emerging global protected area model. Governments should be encouraged to look at their protected area systems through the lens of the 2008 IUCN definition, particularly in developed countries where protected landscapes have sometimes been managed without serious attention to their biodiversity values. A discussion on the role of protected landscapes is urgently needed, particularly in Europe in light of the expansion of the Natura 2000 network. Acceptance of a wider set of management and governance options within protected areas opens up the possibility of bringing new stakeholders more fully into conservation strategies, particularly through the planned and responsible use of privately protected areas and encouragement of effectively run indigenous and community conserved areas. The Australian Indigenous Protected Areas model could be built into many other national strategies.

The World Parks Congress is also a key forum for cementing the role of protected areas in supplying ecosystem services, and developing policy messages that can be carried forward to institutions such as the UN International Strategy for Disaster Reduction, World Health Organization, UN Development Programme, World Bank, and other multi-lateral organizations, UN Convention to Combat Desertification, and industry bodies and research institutions. Despite a high profile in the CBD Programme of Work on Protected Areas (CBD, 2004), issues relating to governance and human rights have still too often stayed at the level of rhetoric, and the growing number of successful case studies of responsible integration of social and ecological needs in protected areas need to be more widely disseminated. The 2014 Congress will provide an important opportunity to make the case. While new and important evidence about the effectiveness of protected areas in conserving biodiversity is expected to be reported, 
further work is needed to understand how different management approaches within protected areas can combine to provide successful biodiversity outcomes. The Congress would be an ideal event to launch further efforts to develop ambitious protected area corridors or networks. At the same time, particular efforts will be needed to address emerging issues, such as the dramatic increase in the wildlife trade, the new techniques needed to plan protected area networks under conditions of climate change, and the political challenges of maintaining protected area policies and budgets during times of fiscal constraint.

Amongst key outcomes that we can expect are an increase in the number and coverage of protected areas, a renewed emphasis on non-state governance approaches, including privately protected areas, a new standard for Key Biodiversity Areas, an agreement on how to achieve just and effective conservation, and the development of partnerships with bodies, communities and peoples outside protected areas who nonetheless benefit from the services these areas provide.

\section{Acknowledgements}

We thank two anonymous reviewers for insightful comments that helped to improve the clarity of the paper.

\section{References}

Al-Dousari, A.M. (2009) Recent studies on dust fallout within preserved and open areas in Kuwait. In Desertification in Arid Lands: Causes, Consequences and Mitigation (eds N.R. Bhat, A.Y. Al-Nasser \& S.A.S. Omar), pp. 137-147. Kuwait Institute for Scientific Research, Kuwait.

Andam, K.S., Ferraro, P.J., Smis, K.R.E., Healy, A. \& Holland, M.D. (2010) Protected areas reduced poverty in Costa Rica and Thailand. Proceedings of the National Academy of Sciences, 107, 9996-10001.

Archer, M. \& Beale, B. (2004) Going Native. Hodder, Adelaide, Australia.

Beever, E.A., Mattsson, B.J., Germino, M.J., van der Burg, M.P., Bradford, J.B. \& Brunson, M.W. (2014) Successes and challenges from formation to implementation of eleven broad-extent conservation programs. Conservation Biology, 28, 302-314.

Beier, P., MAJKA, D.R. \& SPENCER, W.D. (2008) Forks in the road: choices in procedures for designing wildland linkages. Conservation Biology, 22, 836-851.

Berkes, F. (2009) Community conserved areas: policy issues in historic and contemporary context. Conservation Letters, 2, 19-24.

Bertzky, B., Corrigan, C., Kemsey, J., Kenney, S., Ravilous, C., Besançon, C. \& Burgess, N.D. (2012) Protected Planet 2012: Tracking Progress Towards Global Targets for Protected Areas. IUCN, Gland, Switzerland, and UN Environment ProgrammeWorld Conservation Monitoring Centre, Cambridge, UK.

Bhagwat, S. \& Rutte, C. (2006) Sacred groves: potential for biodiversity management. Frontiers of Ecology and Environment, 4, 519-524.

Brockington, D., Duffy, R. \& Igoe, J. (2008) Nature Unbound. Earthscan, London, UK.
Butchart, S.H.M., Scharlemann, J.P.W., Evans, M.I., Quader, S., Arico, S., Arinaitwe, J. et al. (2012) Protecting important sites for biodiversity contributes to meeting global conservation targets. PLOS ONE, 7(3), e32529.

Butchart, S.H.M., Walpole, M., Collen, B., van Strien, A., Scharlemann, J.P.W., Almond, R.E.A. et al. (2010) Global biodiversity: indicators of recent declines. Science, 328, 1164-1168.

Campbell, A., Kapos, V., Lysenko, I., Scharlemann, J., Dickson, B., GibBs, H. et al. (2008) Carbon Emissions from Forest Loss in Protected Areas. UN Environment Programme-World Conservation Monitoring Centre, Cambridge, UK.

Campese, J., Sunderland, T., Greiber, T. \& Oviedo, G. (eds) (2009) Rights-based Approaches: Exploring Issues and Opportunities for Conservation. Center for International Forestry Research and IUCN, Bogor, Indonesia.

CBD (2004) Programme of work on protected areas. Decision VII/28 of the Seventh Meeting of the Conference of Parties to the Convention on Biological Diversity.

CBD (2010) The strategic plan for biodiversity 2011-2020 and the Aichi biodiversity targets. Convention on Biological Diversity Tenth Conference of Parties, Nagoya, Japan, UNEP/CBD/COP/DEC/X/2, 29 October 2010.

Clark, N.E., Boakes, E.H., McGowan, P.J.K., Mace, G.M. \& Fuller, R.A. (2013) Protected areas in South Asia have not prevented habitat loss: a study using historical models of land-use change. PLoS ONE, 8(5), e65298.

Colchester, M. (2003) Salvaging Nature: Indigenous Peoples, Protected Areas and Biodiversity Conservation. World Rainforest Movement and Forest Peoples Programme, Montevideo, Uruguay, and Moreton-in-Marsh, UK.

Collins, A., Fraser, G. \& Snowball, J. (2013) Rhino poaching: supply and demand uncertain. Science, 340, 1166-1167.

Conservation Assured (2013) CA|TS Manual Version 1.1. November 2013, Conservation Assured, Petaling Jaya, Malaysia.

Craigie, I.D., Baillie, J.E.M., Balmford, A., Carbon, C., Collen, B., Green, R. \& Hutton, J.M. (2010) Large mammal population declines in Africa's protected areas. Biological Conservation, 143, 2221-2228.

DAs, S. \& Vincent, J.R. (2009) Mangroves protected villages and reduced death toll during Indian super cyclone. Proceedings of the National Academy of Sciences, 106, 7357-7360.

Department of Conservation (2007) Economic Values of Whangamarino Wetland. Department of Conservation, Auckland, New Zealand.

Dowie, M. (2009) Conservation Refugees. MIT Press, Cambridge, USA, and London, UK.

Dudley, N. (ed.) (2008) Guidelines for Applying Protected Area Management Categories. IUCN, Gland, Switzerland.

Dudley, N., Bhagwat, S., Higgins-Zogib, L., Lassen, B., VerschuURen, B. \& Wild, R. (2010) Conservation of biodiversity in sacred natural sites in Asia and Africa: a review of the scientific literature. In Sacred Natural Sites: Conserving Nature and Culture (eds B. Verschuuren, R. Wild, J. McNeely \& G. Oviedo), pp. 19-32. Earthscan, London, UK.

Dudley, N., Higgins-Zogib, L., Hockings, M., MacKinnon, K., SAndwith, T. \& Stolton, S. (2011a) National parks with benefits: how protecting the planet's biodiversity also provides ecosystem services. Solutions, November-December 2011, 26-34.

Dudley, N., Higgins-Zogib, L. \& Mansourian, S. (2009a) The links between protected areas, faiths, and sacred natural sites. Conservation Biology, 23, 568-577.

Dudley, N., Mansourian, S., Stolton, S. \& Suksawan, S. (2011b) Do protected areas contribute to poverty reduction? Biodiversity, $11,5-7$. 
Dudley, N. \& Stolton, S. (eds) (2003) Running Pure: The Importance of Forest Protected Areas to Drinking Water. WWF International \& The World Bank, Gland, Switzerland, and Washington, DC, USA.

Dudley, N., Stolton, S., Belokurov, A., Krueger, L., Lopoukhine, N., MacKinnon, K. et al. (2009b) Natural Solutions: Protected Areas Helping People Cope with Climate Change. IUCNWCPA, TNC, UNDP, WCS, The World Bank and WWF, Gland, Switzerland, Washington, DC, USA, and New York, USA.

Duffy., R. (2010) Nature Crime: How We're Getting Conservation Wrong. Yale University Press, New Haven, USA, and London, UK.

Emerton, L. \& Pabon-Zamora, L. (2009) Valuing Nature: Why Protected Areas Matter for Economic and Human Wellbeing. The Nature Conservancy, Arlington, USA.

Ferraro, P.J. \& Hanauer, M.M. (2014) Quantifying causal mechanisms to determine how protected areas affect poverty through changes in ecosystem services and infrastructure. Proceedings of the National Academy of Sciences, 111, 4332-4337.

Ferraro, P., Hanauer, M.M., Miteva, D.A., CanavireBacarreza, J.V., Pattanayak, S.K. \& Sims, K.R.E. (2013) More strictly protected areas are not necessarily more protective: evidence from Bolivia, Costa Rica, Indonesia, and Thailand. Environmental Research Letters, 8, 025011.

Fitzsimons, J., Legge, S., Traill, B. \& Woinarski, J. (2010) Into Oblivion: The Disappearing Native Mammals of Northern Australia. The Nature Conservancy, Australian Wildlife Conservancy and Pew Environmental Group, Melbourne, Australia.

Geldmann, J., Barnes, M., Coad, L., Craigie, I.D., Hockings, M. \& BURGESS, N.D. (2013) Effectiveness of terrestrial protected areas in reducing habitat loss and population declines. Biological Conservation, 161, 230-238.

Global Environmental Facility (2013) Policy on Agency Minimum Standards on Environmental and Social Safeguards. Policy PL/SD/o3 September 12 2013, Global Environmental Facility, Washington, DC, USA.

Halpern, B.S. (2003) The impact of marine reserves: do reserves work and does reserve size matter? Ecological Applications, 13, 117-137.

Hannah, L., Midgley, G.F., Andelman, S., Araújo, M., Hughes, G., Martinez-Meyer, E. et al. (2007) Protected area needs in a changing climate. Frontiers of Ecology and the Environment, 5, 131-138.

He, G., Xiaodong, C., Wei, L., Scott, B., Shiqiang, Z., YeQING Cheng, L. et al. (2008) Distribution of economic benefits from ecotourism: a case study of Wolong nature reserve for giant pandas in China. Environmental Management, 42, $1017-1025$.

Heller, N.E. \& Новвs, R.J. (2014) Development of a natural practice to adapt conservation goals to global change. Conservation Biology, 28, 696-704.

Hockings, M., Stolton, S. \& Dudley, N. (2004) Management effectiveness: assessing management of protected areas? Journal of Environmental Policy and Planning, 6, 157-174.

Holt, F.L. (2005) The Catch-22 of conservation: indigenous peoples, biologists and cultural change. Human Ecology, 33, 199-205.

Hvenegaard, G.T., Butler, J.R. \& Krystofiak, D.K. (1989) Economic values of bird watching at point Pelee National Park, Canada. Wildlife Society Bulletin, 17, 526-531.

IUCN (2005) Benefits Beyond Boundaries: Proceedings of the Vth IUCN World Parks Congress. IUCN, Gland, Switzerland.

iUCN/WCMC (World Conservation Monitoring Centre) (1994) Guidelines for Protected Area Management Categories. IUCN, Gland, Switzerland, and Cambridge, UK.
IUCN NCUK (National Committee for the UK) (2012) Putting Nature on the Map: Identifying Protected Areas in the UK-A Handbook to Help Identify Protected Areas in the UK and Assign the IUCN Categories and Governance Types to Them. IUCN National Committee for the UK. Http://www.iucn-uk.org/Portals/o/PNOTM \%2ohandbook\%2osmall.pdf [accessed 7 July 2014].

Johnston, A., Ausden, M., Dodd, A.M., Bradbury, R.B., Chamberlain, D.E., Jiguet, F. et al. (2013) Observed and predicted effects of climate change on species abundance in protected areas. Nature Climate Change, 3, 1055-1061.

Joppa, L.N., Loarie, S.R. \& Pimm, S.L. (2008) On the protection of 'protected areas'. Proceedings of the National Academy of Sciences, $105,6673-6678$.

Lawler, J.J., Shafer, S.L., White, D., Kareiva, P., Maurer, E.P., Blaustein, A.R. \& Bartlein, P.J. (2009) Projected climateinduced faunal change in the Western Hemisphere. Ecology, 90, 588-597.

Leisher, C., Touval, J., Hess, S.M., Boucher, T.M. \& Reymondin, L. (2013) Land and forest degradation inside protected areas in Latin America. Diversity, 5, 779-795.

Lele, S., Wilshusen, P., Brockington, D., Seidler, R. \& Bawa, K. (2010) Beyond exclusion: alternative approaches to biodiversity conservation in the developing tropics. Current Opinion in Environmental Sustainability, 2, 1-7.

Leverington, F., Lemos Costa, K., Pavese, H., Lisle, A. \& Hockings, M. (2010) A global analysis of protected area management effectiveness. Environmental Management, 46, 685-698.

Locke, H. (2013) Nature needs half: a necessary and hopeful new agenda for protected areas. PARKS, 19, 13-22.

Locke, H. \& DeArdon, P. (2005) Rethinking protected area categories and the new paradigm. Environmental Conservation, $32,1-10$.

Lysenko, I., Besançon, C. \& Savy, C. (2007) 2007 UNEPWCMC Global List of Transboundary Protected Areas. UN Environment Programme-World Conservation Monitoring Centre, Cambridge, UK.

Maekawa, M., Lanjouw, A., Rutagarama, E. \& Sharp, D. (2013) Mountain gorilla tourism generating wealth and peace in post-conflict Rwanda. Natural Resources Forum, 37, 127-137. Mallarach, J.M., Morrison, J., Kothari, A., Sarmiento, F., Atauri, J.A. \& Wishitemi, B. (2008) In defence of protected landscapes: a reply to some criticisms of Category V protected areas and suggestions for improvement. In Defining Protected Areas: An International Conference in Almeria, Spain, May 2007 (eds N. Dudley \& S. Stolton), pp. 31-37. IUCN World Commission on Protected Areas, Gland, Switzerland.

Mascia, M.B., Pailler, S., Krithivasan, R., Roshchanka, V., Burns, D., Mlotha, M.J. et al. (2014) Protected area downgrading, downsizing, and degazettement (PADDD) in Africa, Asia, and Latin America and the Caribbean, 1900-2010. Biological Conservation, 169, 355-361.

Mawdsley, J.R., O’Malley, R. \& OJima, D.S. (2009) A review of climate-change adaptation strategies for wildlife management and biodiversity conservation. Conservation Biology, 23, 1080-1089.

Mвaiwa, J.E. (2004) The socio-cultural impacts of tourism development in the Okavango Delta, Botswana. Journal of Tourism and Cultural Change, 2, 3.

Miteva, D.A., Pattanayak, S.K. \& Ferraro, P.J. (2012) Evaluation of biodiversity policy instruments: what works and what doesn't? Oxford Review of Economic Policy, 28, 69-92.

Mora, C. \& SALE, P.F. (2011) Ongoing global biodiversity loss and the need to move beyond protected areas: a review of the technical and 
practical shortcomings of protected areas on land and sea. Marine Ecology Progress Series, 434, 251-266.

NAGendRA, H. (2008) Do parks work? Impact of protected areas on land cover clearing. Ambio, 37, 330-337.

Naidoo, R. \& Ricketts, T.H. (2006) Mapping the economic costs and benefits of conservation. PLoS Biology, 4(11), e360.

Nelson, A. \& Chомiтz, K.M. (2011) Effectiveness of strict vs multiple use protected areas in reducing tropical forest fires: a global analysis using matching methods. PLoS ONE, 6(8), e22722.

NeWMARK, W.D. (1995) Extinction of mammal populations in Western North American National Parks. Conservation Biology, 9, 512-526.

Ninan, K.N. \& Sathyapalan, J. (2005) The economics of biodiversity conservation: a study of a coffee growing region in the Western Ghats of India. Ecological Economics, 55, 61-72.

Parques Nacionales Naturales de Colombia (2007) Justificación para la Declaración del Area protegida. Parques Nacionales Naturales de Colombia, Bogotá, Colombia.

Pasquini, L., Fitzimons, J.A., Cowell, S., Brandon, K. \& Wescott, G. (2011) The establishment of large private nature reserves by conservation NGOs: key factors for successful implementation. Oryx, 45, 373-380.

Perret, S., Dolf, F. \& Kienholz, H. (2004) Rockfalls into forests: analysis and simulation of rockfall trajectories-considerations with respect to mountainous forests in Switzerland. Landslides, 1, 123-130.

Redford, K.R. \& Painter, M. (2006) Natural Alliances Between Conservationists and Indigenous Peoples. Wildlife Conservation Society Working Paper number 25. Wildlife Conservation Society, New York, USA.

Rissman, A.R. \& SAYre, N.F. (2012) Conservation outcomes and social relations: a comparative study of private ranchland conservation easements. Society and Natural Resources, 25, 523-538.

Rodrigues, A.S.L., Andelman, S.J., Bakarr, M.I., Boitani, L., Brooks, T.M., Cowling, R.M. et al. (2004) Effectiveness of the global protected area network in representing species diversity. Nature, 428, 640-643.

Rosen, G.E. \& Smith, K.F. (2010) Summarizing the evidence on the international trade in illegal wildlife. Ecohealth, 7, 24-32.

Scott, J.M., Davis, F.W., McGhie, R.G., Wright, R.G., Groves, C. \& Estes, J. (2001) Nature reserves: do they capture the full range of America's biological diversity? Ecological Applications, 11, 999-1007.

Scott, J.M., Goble, D.D., Haines, A.M., Wiens, J.A. \& Neel, M.C. (2010) Conservation-reliant species and the future of conservation. Conservation Letters, 3, 91-97.

$\mathrm{S}_{\mathrm{My}}$, D. (2006) Indigenous protected areas in Australia. Parks, $16,14-20$.
Stolton, S., Boucher, T., Dudley, N., Hoekstra, J., Maxted, N. \& KELL, S. (2008a) Ecoregions with crop wild relatives are less well protected. Biodiversity, 9, 52-55.

Stolton, S. \& Dudley, N. (eds) (2010a) Arguments for Protected Areas: Multiple Benefits for Conservation and Use. Earthscan, London, UK.

Stolton, S. \& Dudley, N. (2010b) Vital Sites: The Contribution of Protected Areas to Human Health. WWF and Equilibrium Research, Gland, Switzerland.

Stolton, S., Dudley, N. \& Randall, J. (2008b) Natural Security: Protected Areas and Hazard Mitigation. WWF International, Gland, Switzerland.

Stolton, S., Redford, K., Dudley, N., Adams, W., Corcuera, E. \& Mitchell, B.A. (eds) (in press) The Futures of Privately Protected Areas. IUCN, Gland, Switzerland.

Svancara, L.K., Brannon, R., Scott, J.M., Groves, C.R., Noss, R.F. \& Pressey, R.L. (2005) Policy-driven vs evidence-based conservation: a review of political targets and biological needs. BioScience, 55, 989-995.

Van Beukering, P.J.H., Cesar, H.S.J. \& Janssen, M.A. (2003) Economic valuation of the Leuser National Park on Sumatra, Indonesia. Ecological Economics, 44, 43-62.

Vasilijević, M., Zunckel, K., McKinney, M., Erg, B., Schoon, M. \& Rosen Michel, T. (in press) Transboundary Conservation: A Global Guide. IUCN, Gland, Switzerland.

Walston, J., Robinson, J.G., Bennett, E.L., Breitenmoser, U., Da Fonseca, G.A.B., Goodrich, J. et al. (2010) Bringing the tiger back from the brink-the six percent solution. PLoS Biology, 8(9), e1000485.

\section{Biographical sketches}

Nigel DUdLey is an environmental consultant, focusing primarily on issues relating to protected areas and broadscale approaches to conservation, particularly in forest ecosystems. He is chair of the IUCN World Commission on Protected Areas specialist group on Natural Solutions, which addresses ecosystem services from protected areas. Craig Groves is a Senior Scientist with The Nature Conservancy's Science for Nature and People Initiative. He also serves as the Series Editor for the IUCN World Commission on Protected Areas Best Practice Guidelines series. Kent H. Redford is a conservation practitioner with experience in academia and the conservation NGO sector, and with interests in protected areas, mammalian conservation, and the role synthetic biology could play in helping achieve conservation outcomes. SUE STOLTON's work focuses on protected areas, particularly with respect to international conventions, assessment of management effectiveness, planning and standards, and issues related to understanding the wider values and benefits that protected areas can provide. 